\title{
Reworked microfossils as a paleogeographic tool
}

\author{
Claudius Pirkenseer, Silvia Spezzaferri, and Jean-Pierre Berger \\ Department of Geosciences, Section Geology-Paleontology, University of Fribourg, Chemin du Musée 6, CH-1700 Fribourg, Switzerland
}

\begin{abstract}
The abundant occurrence of reworked microfossils within the paleogeographically restricted Upper Rhine Graben of central Europe represents a unique opportunity to investigate their inherent information, allowing new insights into the paleogeographic framework and past sedimentary pathways. In the late Rupelian and early Chattian a transgression-regression cycle linked to the global Ru2-Ru3 sequences affected the entire Upper Rhine Graben basin, leading to the deposition of a thick marine to lacustrine series. The occurrences of abundant reworked planktonic foraminifera are grouped into several events that are linked to intervals of increased clastic input during regressive phases. The biostratigraphic ranges of the reworked taxa indicate Late Cretaceous, Ypresian, Lutetian, and Bartonian-Priabonian ages for the sediment sources. The reworking originated from related west alpine source deposits via a northward-draining fluviatile system. A fast uplift of Priabonian and older deposits within the alpine realm during the late Rupelian is accordingly inferred, confirming the increased rate of the mesoalpine orogeny at that time. The careful analysis of reworked microfossil assemblages thus provides a valid tool for future paleogeographic, tectonic, and provenance studies.
\end{abstract}

\section{INTRODUCTION}

Reworked microfossils are generally considered to hinder the interpretation of microfossil assemblages. Few studies have used reworked microfossils as tool for reconstructing ocean circulation or tectonic and sedimentary hinterland evolution (e.g., Ferreira et al., 2008; Lidz and McNeill, 1995; Scott and Medioli, 1988).

The paleogeographically restricted Upper Rhine Graben, the central part of the European continental rift system (Dèzes et al., 2004; Figs. 1A and1B), represents an opportunity for studying the provenance and significance of reworked microfossils. During the late Rupelian, an extensive transgression-regression cycle related to the global Ru2-Ru3 sequences affected the entire basin and led to the deposition of the several-hundredmeters-thick marine "Gray Series" and the subsequent lacustrine Niederroedern Formation (Fig. 1D). Previous studies reported reworked microfossils and nannofossils and heavy minerals from Oligocene Upper Rhine Graben deposits and conjectured their alpine origin and transportation by marine currents via the Swiss Molasse Basin (e.g., Fischer, 1965; Martini 1990; Spiegel et al., 2007). Abundant reworked Cretaceous planktonic foraminifera are documented from the Mainz Basin (Schäfer and Kuhn, 2004; Grimm et al., 2005; Schäfer, 2000) and the Upper Rhine Graben (Fischer, 1965). Reworked planktonic foraminifera are also documented from Rupelian and Chattian western subalpine and Swiss Plateau Molasse deposits (Fischer, 1965; Weidmann et al., 1982; Ujetz et al., 1994).

The magnitude and distribution of reworked planktonic foraminifera recorded in this study justifies a selective focus on their inherent information and a more critical integration in new and published lithostratigraphic, paleogeographic, and paleontologic data.

\section{METHODS}

Material used for this study was derived from the drill holes Allschwil-2 (southwestern Basel) and DP-202 (northern Mulhouse) (Fig. 1C; Fig. DR2 [with well logs] in the GSA Data Repository ${ }^{1}$ ) spanning the Paleogene basin fill as well as field outcrops. Additional samples were available from Rupelian to Chattian sediments of the Jura Molasse further to the south.
The samples from DP-202 were treated with hydrogen peroxide and wet sieved through $63-1000 \mu \mathrm{m}$ meshes. To obtain a maximum diversity of the microfossil assemblages, we screened the whole dry fractions from 250 to $1000 \mu \mathrm{m}$ and a sufficient amount of the $63-125 \mu \mathrm{m}$ material.

\section{RESULTS}

Magnitude and Range of Reworked Planktonic Foraminifera

There have been 18 Eocene species found in the research area, including two Thanetian-Ypresian (e.g., Morozovella subbotinae) and two post-Lutetian (e.g., Turborotalia cocoaensis) taxa. The acarininids provide the most abundant and diverse group (six species). The rare presence of Chiloguembelina midwayensis (Paleocene) is questionable due to poor preservation. The eight Late Cretaceous taxa are grouped in Cenomanian (e.g., Rotalipora brotzeni), Turonian to Santonian (Marginotruncana pseudolinneiana), and Campanian to Maastrichtian (e.g., Heterohelix striata) intervals. The ranges of three taxa start in the Albian (e.g., Muricohedbergella delrioensis).

Late Cretaceous, Ypresian, Lutetian, and Bartonian-Priabonian ages are accordingly inferred for the sediment sources based on the combined biostratigraphic ranges of the recorded taxa. No clear age shifts within the reworked assemblages can be observed between subsequent samples.

\section{Stratigraphic Distribution of the Reworked Material}

Reworked material at the drilling sites DP-202 and Allschwil-2 first appears after the initial transgressive and highstand units (TST [transgressive system tract] Ru2, MF [foraminifera marls] Ru2; Figs. 2A, $2 \mathrm{~B}$, and $1 \mathrm{D})$ of the second Rupelian transgression into the Upper Rhine Graben. The reworked material ranges from the marine sediments of the late Rupelian "Meletta Beds" well into the freshwater beds of the early Chattian Niederroedern Formation (Pirkenseer et al., 2010; Fig DR2).

Five consecutive episodes of reworking take place in the drill hole Allschwil-2. All five events are generally linked to increased input of coarser clastic material in turbiditic pro-delta, delta-front, and fluviatile settings and include Late Cretaceous and Paleogene taxa. They all relate to the lowermost and middle Meletta Beds (regressive system tract, RST Ru2; Fig. 2C), the "Cyrena Marls" (RST Ru3; Fig. 2E) and the Niederroedern Formation (Fig. 2F). During the first three episodes the abundance and diversity increases, with a peak during the Cyrena Marls (Fig. 2E). Three brief episodes occur in the middle and upper Meletta Beds at drill hole DP-202. The diversity and abundance of reworked specimens are linked to the increased clastic input, and rise throughout the Cyrena Marls. Cretaceous taxa only occur in the upper part of this stratigraphic unit. A single sample from the Niederroedern Formation yielded one Paleogene species.

The samples available from Rupelian and Chattian sediments of the Jura Molasse yielded Cretaceous and Paleogene reworked foraminifera.

\section{DISCUSSION OF SOURCE AREAS \\ Cretaceous}

Widespread Late Cretaceous sedimentation covered the Helvetic shelf and adjacent areas around the Rhenish Massif (Dercourt et al., 2000). Prior to the initial Paleogene sedimentation of terrestrial Lutetian to

${ }^{1}$ GSA Data Repository item 2011245, Figure DR1 (range chart of reworked planktonic foraminifera taxa) and Figure DR2 (lithostratigraphic position of reworking events and sequence boundaries in drill core logs), is available online at www.geosociety.org/pubs/ft2011.htm, or on request from editing@geosociety.org or Documents Secretary, GSA, P.O. Box 9140, Boulder, CO 80301, USA. 


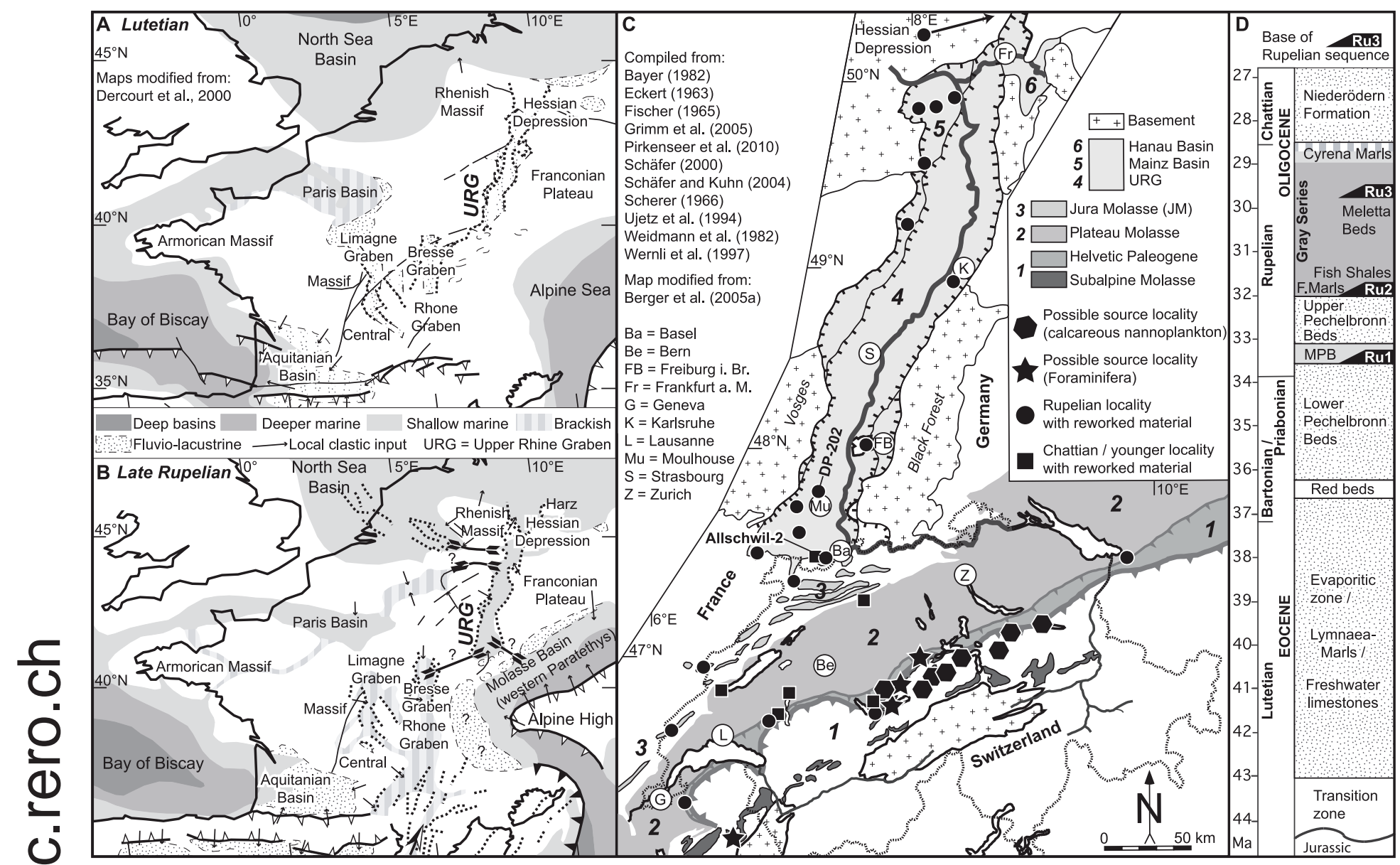

Figure 1. A, B: Western European paleogeography during late Paleogene. URG-Upper Rhine Graben. C: Map of research area indicating possible source areas and localities with reworked microfossils. D: Upper Rhine Graben lithostratigraphy. F.Marls-Foraminifera Marls; MPB-Middle Pechelbronn Beds; double arrows represent possible marine connections.

Priabonian pisolithic clays, the entire Cretaceous succession was eroded within the research area and adjacent areas to the south. An unconformity between the Late Jurassic to Early Cretaceous and the Eocene also exists in the northwestern Helvetic realm (Herb, 1988; Berger et al., 2005b). This implies a source for Late Cretaceous to Ypresian foraminifera species further to the south or southeast. Fischer (1965) proposed marginal alpine source rocks such as the "Couches rouges" of the "Klippen Belt."

Sediments of the lower "Niesenflysch" (Bernese Oberland, central Switzerland) contain Late Cretaceous planktonic foraminifera (e.g., Contusotruncana fornicata), while the younger upper Niesenflysch deposits yield autochthonous Ypresian to Lutetian nummulites as well as reworked Cretaceous material (Ackermann, 1986).

\section{Paleogene}

The pre-Rupelian of the Upper Rhine Graben consists of continental evaporitic and lacustrine sediments (Berger et al., 2005a, 2005b; Roussé, 2006); therefore an in situ provenance of reworked material caused by regional synrift uplift can be ruled out (Figs. 1A, 1B, and 1D).

The Eocene-Oligocene successions of the adjacent basins (France, Belgium, northern Germany, and England) can be excluded as a source as well, because they were not exposed to erosion in the late Rupelian (Vinken, 1988) or were paleogeographically isolated (Dercourt et al., 2000; Sissingh, 2006) (Fig. 1A). The great distance and the direction of sedimentary discharge in the late Rupelian of the research area (Roussé, 2006) contradict a supply from the north. Though a stepwise northwest- ward progression of the Helvetic shelf and the adjacent foreland bulge is observable in the Paleocene and Eocene (e.g., Herb, 1988; Kempf and Pfiffner, 2004), marine sediments were never deposited to the north (e.g., the future Swiss Jura region), and therefore were not subject to a late Rupelian outer alpine uplift and erosion (Fig. 1A).

Widespread deep- to shallow-marine sediments were deposited in the future alpine realm during the Paleocene and Eocene (e.g., Herb, 1988; Menkveld-Gfeller, 1995) (Fig. 1A). Possible source rocks yielding Eocene planktonic foraminifera include the "Grès de Samoens" (Wernli et al., 1997), the Habkern Mélange (Bayer, 1982) and the "Globigerina Marls" (Eckert, 1963) in central to southwestern Switzerland. A more southern provenance includes the marine sediments of LutetianPriabonian age of the western Alps (Pairis, 1988) in southeastern France. In combination with the increased rate of the late mesoalpine orogeny (Sissingh, 2006), this suggests a southwestern alpine provenance of the reworked foraminifera.

\section{INTERPRETATION}

Several researchers support the idea of transport of reworked material from the developing alpine range by marine currents (Fischer, 1965; Kuhlemann and Kempf, 2002; Martini, 1990; Sissingh, 2006; Spiegel et al., 2007). This implies the rather unlikely scenario of an initial deposition of eroded source material into the North Alpine Foreland Basin and a subsequent transport perpendicular to a southwest-northeast-directed axial paleocurrent system (Diem, 1986). Furthermore, the depocenter of 


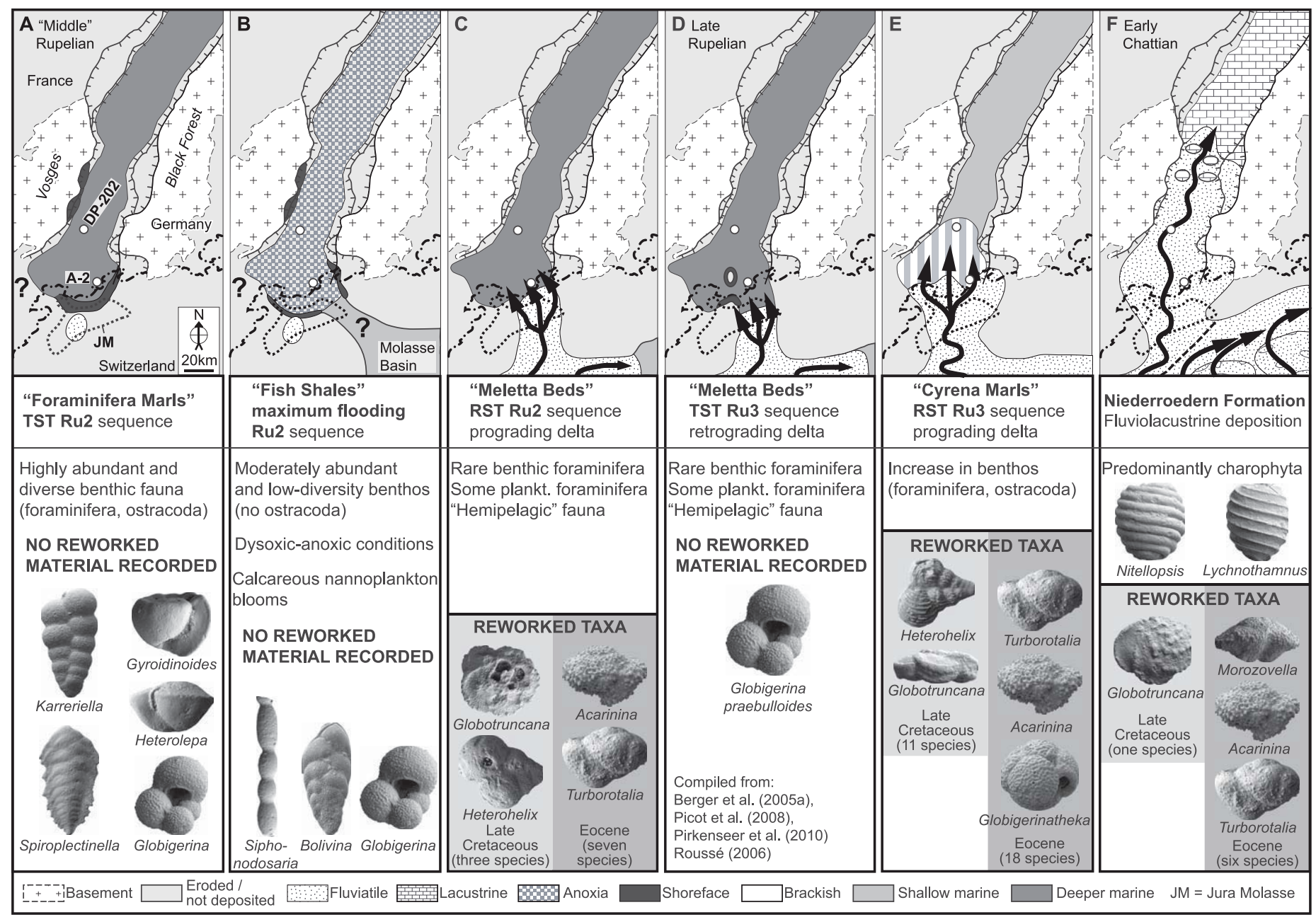

Figure 2. A-F: Paleogeographic evolution and distribution of reworked planktonic foraminifera in research area. TST-transgressive system tract; RST—regressive system tract; plankt.—planktonic; thick black lines represent fluviatile flux directions.

the Molasse Basin during deposition of the Lower Marine Molasse was located to the northeast (toward the Bavarian alpine front), with pinching out of shallower marine sediments to the west and north on the intermediate foreland bulge (e.g., Kuhlemann and Kempf, 2002). While suspended transport of reworked nannoplankton by marine currents is possible, bedload transport of sand-sized material seems highly unlikely between the two basins.

Schäfer and Kuhn (2004) and Roussé (2006) assumed a direct fluviatile transport from northwest alpine origins. The development of an extensive deltaic system on the southern margin of the Upper Rhine Graben (Figs. 2C-2E) at the debut of the Meletta Beds was demonstrated by Roussé (2006), with main paleocurrents directed to the north. The fast progradation likely choked the short-lived marine connection to the Molasse Basin after the highstand of the Ru2 sequence due to the lowering of the base level during the regressive system tract (Fig. 2C). This is supported by the successive south to north onset of fluviolacustrine sedimentation in the Jura Molasse (Picot et al., 2008), and in drill holes Allschwil-2 and DP-202 (Figs. 2A-2E).

There are paleogeographic implications from the timing of the regression of the sea in the Molasse Basin, which (according to Berger et al., 2005a, 2005b) retreated to central Switzerland in the late Rupelian (nannoplankton zone NP24). In the western part of the Swiss Molasse Basin vast alluvial fans started to develop over the marine fan deltas and basinal sediments, redirecting the general WSW-ENE axial drainage pat- tern in the narrower southwestern part of the basin by sediment overfill. While the rapidly ENE-ward-regressing Molasse Sea continued to be fed by axial tributaries, the massive clastic accumulations in the southwestern part of the Swiss Molasse Basin overrode the moderate paleorelief of the foreland bulge and triggered a fluviatile system draining into the southern Upper Rhine Graben shortly after the highstand of the Ru2 sequence (Figs. 2C-2F).

The scarce occurrences of allochthonous foraminifera in the latest Rupelian to early Chattian fluviatile to lacustrine Niederroedern Formation (Fig. 1D) of the southern Upper Rhine Graben imply a decreasing drainage gradient and/or the shift to different source areas. As abundant reworked taxa are recorded from numerous localities in the Lower Freshwater Molasse of Switzerland (Fig. 1C), a Chattian separation of the Molasse and Upper Rhine Graben drainage systems seems likely (Fig. 2F).

\section{CONCLUSIONS}

The distribution of abundant allochthonous planktonic foraminifera from the late Rupelian to early Chattian in Upper Rhine Graben deposits testifies to several reworking events linked to intervals of increased clastic input during regressive phases of the Ru2-Ru3 sequences. Late Cretaceous, Ypresian, Lutetian, and Priabonian ages are inferred for the sediment sources based on the combined biostratigraphic ranges of the recorded taxa. Reworking of planktonic foraminifera from related west alpine source deposits following overfill of the western Molasse 
Basin via a northward-draining fluviatile system is proposed. This is synchronous with the development of a vast prograding delta architecture at the southern margin of the Upper Rhine Graben and the retreat of the western Molasse Sea in the late Rupelian. Displacement of reworked material by marine currents via the Swiss Molasse Basin is ruled out because of unfavorable paleotopographic and paleogeographic constraints.

The fast uplift of Priabonian and older deposits within the alpine realm during the late Rupelian can accordingly be inferred, confirming the increased rate of the mesoalpine orogeny at that time. A Chattian separation of the fluviatile sediment transport between the western Molasse Basin and the Upper Rhine Graben is observed.

The careful analysis of the inherent information of reworked microfossil assemblages thus provides critical information on sediment provenance, hinterland uplift history, and paleogeographic interpretations, furnishing a valid tool for future studies.

\section{ACKNOWLEDGMENTS}

This study was carried out with funding from the Swiss National Science Foundation (SNF 200020-109457/118025). We thank Stéphane Roussé for arranging the sampling of the DP-202 core and helping out with sedimentologic data. The Natural History Museum of Basel supplied the material of the Allschwil-2 core. Hermann Fischer provided information concerning the Allschwil-2 hole. We also thank three anonymous reviewers whose comments helped to improve the manuscript.

\section{REFERENCES CITED}

Ackermann, A., 1986, Le Flysch de la nappe du Niesen: Eclogae Geologicae Helvetiae, v. 79, p. 641-684.

Bayer, A.A., 1982, Untersuchungen im Habkern-Melange ("Wildflysch") zwischen Aare und Rhein [Ph.D. thesis]: Eidgenössische Technische Hochschule Zürich, 327 p.

Berger, J.-P., Reichenbacher, B., Becker, D., Grimm, M., Grimm, K., Picot, L., Storni, A., Pirkenseer, C., Derer, C., and Schaefer, A., 2005a, Paleogeography of the Upper Rhine Graben (URG) and the Swiss Molasse Basin (SMB) from Eocene to Pliocene: International Journal of Earth Sciences, v. 94, p. 697-710, doi:10.1007/s00531-005-0475-2.

Berger, J.-P., Reichenbacher, B., Becker, D., Grimm, M., Grimm, K., Picot, L., Storni, A., Pirkenseer, C., and Schaefer, A., 2005b, Eocene-Pliocene time scale and stratigraphy of the Upper Rhine Graben (URG) and the Swiss Molasse Basin (SMB): International Journal of Earth Sciences, v. 94, p. 711731, doi:10.1007/s00531-005-0479-y.

Dercourt, J., Gaetani, M., Vrielynck, B., Barrier, E., Biju-Duval, B., Brunet, M.F., Cadet, J.P., Crasquin, S., and Sandulescu, M., eds., 2000, Atlas Peri-Tethys, palaeogeographical maps: Paris, Commission for the Geological Map of the World, 24 maps, scale 1:10 000000,269 p.

Dèzes, P., Schmid, S.M., and Ziegler, P.A., 2004, Evolution of the European Cenozoic rift system: Interaction of the Alpine and Pyrenean orogens with their foreland lithosphere: Tectonophysics, v. 389, p. 1-33, doi:10.1016/ j.tecto.2004.06.011.

Diem, B., 1986, Die Untere Meeresmolasse zwischen Saane (Westschweiz) und der Ammer (Oberbayern): Eclogae Geologicae Helvetiae, v. 79, p. 493-559.

Eckert, H.R., 1963, Die obereozänen Globigerinen-Schiefer (Stad- und Schimbergschiefer) zwischen Pilatus und Schrattenfluh: Eclogae Geologicae Helvetiae, v. 56, p. 1002-1072.

Ferreira, J., Cachão, M., and González, R., 2008, Reworked calcareous nannofossils as ocean dynamic tracers: The Guadiana shelf case study (SW Iberia): Estuarine, Coastal and Shelf Science, v. 79, p. 59-70, doi:10.1016/ j.ecss.2008.03.012.

Fischer, H., 1965, Geologie des Gebietes zwischen Blauen und Pfirter Jura: Beiträge zur Geologischen Karte der Schweiz, Neue Folge, v. 122, 126 p.

Grimm, K.I., Köthe, A., and Grimm, M., 2005, Sedimentologie und Biostratigraphie im Rupelium der Ziegeleigrube Jungk, Wöllstein (Mainzer Becken): Senckenbergiana Lethaea, v. 85, p. 231-259.

Herb, R., 1988, Eocaene Paläogeographie und Paläotektonik des Helvetikums: Eclogae Geologicae Helvetiae, v. 81, p. 611-657.

Kempf, O., and Pfiffner, O.A., 2004, Early Tertiary evolution of the North Alpine Foreland Basin of the Swiss Alps and adjoining areas: Basin Research, v. 16, p. 549-567, doi:10.1111/j.1365-2117.2004.00246.x.
Kuhlemann, J., and Kempf, O., 2002, Post-Eocene evolution of the North Alpine Foreland Basin and its response to Alpine tectonics: Sedimentary Geology, v. 152 , p. 45-78, doi:10.1016/S0037-0738(01)00285-8.

Lidz, B.H., and McNeill, D.F., 1995, Reworked Paleogene to early Neogene planktic foraminifera: Implications of an intriguing distribution at a late Neogene prograding margin, Bahamas: Marine Micropaleontology, v. 25, p. 221-268.

Martini, E., 1990, The Rhinegraben system, a connection between northern and southern seas in the European Tertiary: Veröffentlichungen aus dem Übersee-Museum Bremen, Reihe A, Heft 10, p. 83-98.

Menkveld-Gfeller, U., 1995, Stratigraphie, Fazies und Palaeogeographie des Eocaens der helvetischen Decken der Westschweiz (Diablerets- und Wildhorn-Decke): Eclogae Geologicae Helvetiae, v. 88, p. 115-134.

Pairis, J.-L., 1988, Paleogène marin et structuration des Alpes occidentals francaises (domains externe et confines sud-occidentaux du Subbbrianconnais) [Ph.D. thesis]: Grenoble, Joseph-Fourier University, 501 p.

Picot, L., Becker, D., Cavin, L., Pirkenseer, C., Lapaire, F., Rauber, G., Hochuli, P.A., Spezzaferri, S., and Berger, J.-P., 2008, Sédimentologie et paléontologie des paléoenvironnements côtiers des dépôts de l'UMM rhénane dans le Jura suisse: Swiss Journal of Geosciences, v. 101, p. 483-513, doi:10.1007/ s00015-008-1275-z.

Pirkenseer, C., Spezzaferri, S., and Berger, J.-P., 2010, Palaeoecology and biostratigraphy of the Paleogene foraminifera from the southern Upper Rhine Graben and the influence of reworked planktonic Foraminifera: Palaeontographica, Abteilung A, v. 293, p. 1-93.

Roussé, S., 2006, Architecture et dynamique des séries marines et continentales de l'Oligocène Moyen et Supérieur du Sud du Fossé Rhénan: Evolution des milieux de dépôt en contexte de rift en marge de l'avant-pays alpin [Ph.D. thesis]: Strasbourg, Université Louis Pasteur, 471 p., http://scd-theses .u-strasbg.fr/1244/01/ROUSSE2006.pdf.

Schäfer, P., 2000, Zur Stratigraphie und Genese der tertiären Sedimente zwischen Eisenberg und Lautersheim im südwestlichsten Teil des Mainzer Beckens: Jahresbericht und Mitteilungen des Oberrheinischen Geologischen Vereins, Neue Folge, v. 82, p. 175-222.

Schäfer, P., and Kuhn, W., 2004, Mikropaläontologische und lithologische Abgrenzungskriterien zwischen Oberem Rupelton [=Rosenberg Subformation] und "Schleichsand" [=Stadecken Formation] im Rupelium (Tertiär) des Mainzer Beckens: Mainzer Geowissenschaftliche Mitteilungen, v. 32, p. $139-178$.

Scherer, F., 1966, Geologisch-Palaeontologische Untersuchungen im Flysch und in der Molasse zwischen Thunersee und Eriz (Kt. Bern): Beiträge zur Geologischen Karte der Schweiz, Neue Folge, v. 127, 115 p.

Scott, D.B., and Medioli, F.S., 1988, Tertiary-Cretaceous reworked microfossils in Pleistocene glacial-marine sediments: An index to glacial activity: Marine Geology, v. 84, p. 31-41, doi:10.1016/0025-3227(88)90123-5.

Sissingh, W., 2006, Syn-kinematic palaeogeographic evolution of the West European Platform: Correlation with Alpine plate collision and foreland deformation: Netherlands Journal of Geosciences, v. 85, p. 131-180.

Spiegel, C., Kuhlemann, J., and Frisch, W., 2007, Tracing sediment pathways by zircon fission track analysis: Oligocene marine connections in Central Europe: International Journal of Earth Sciences, v. 96, p. 363-374, doi: 10.1007/s00531-006-0097-3.

Ujetz, B., Kindler, P., and Wernli, R., 1994, Oligocene foraminifera from the Val d'Illiez Formation (Haute-Savoie, France): Refined biostratigraphy and paleoecological analysis: Revue de Micropaleontologie, v. 37, p. 275-287.

Vinken, R., compiler, 1988, The northwest European Tertiary Basin. Results of the International Geological Correlation Programme, Project no. 124: Geologisches Jahrbuch, Reihe A, Heft 100, 508 p.

Weidmann, M., Homewood, P., and Fasel, J.-M., 1982, Sur les terrains subalpins et le Wildflysch entre Bulle et Montreux: Bulletin de la Société Vaudoise des Sciences Naturelles, v. 362, p. 151-183.

Wernli, R., Morend, D., and Piguet, B., 1997, Les foraminifères planctoniques en sections de l'Eocène et de l'Oligocène des Grés de Samoens (Ultrahelvétique du massif de Platé, Haute-Savoie, France): Eclogae Geologicae Helvetiae, v. 90, p. 581-590. 